Springer Link

Computational Science and Its Applications - ICCSA 2019

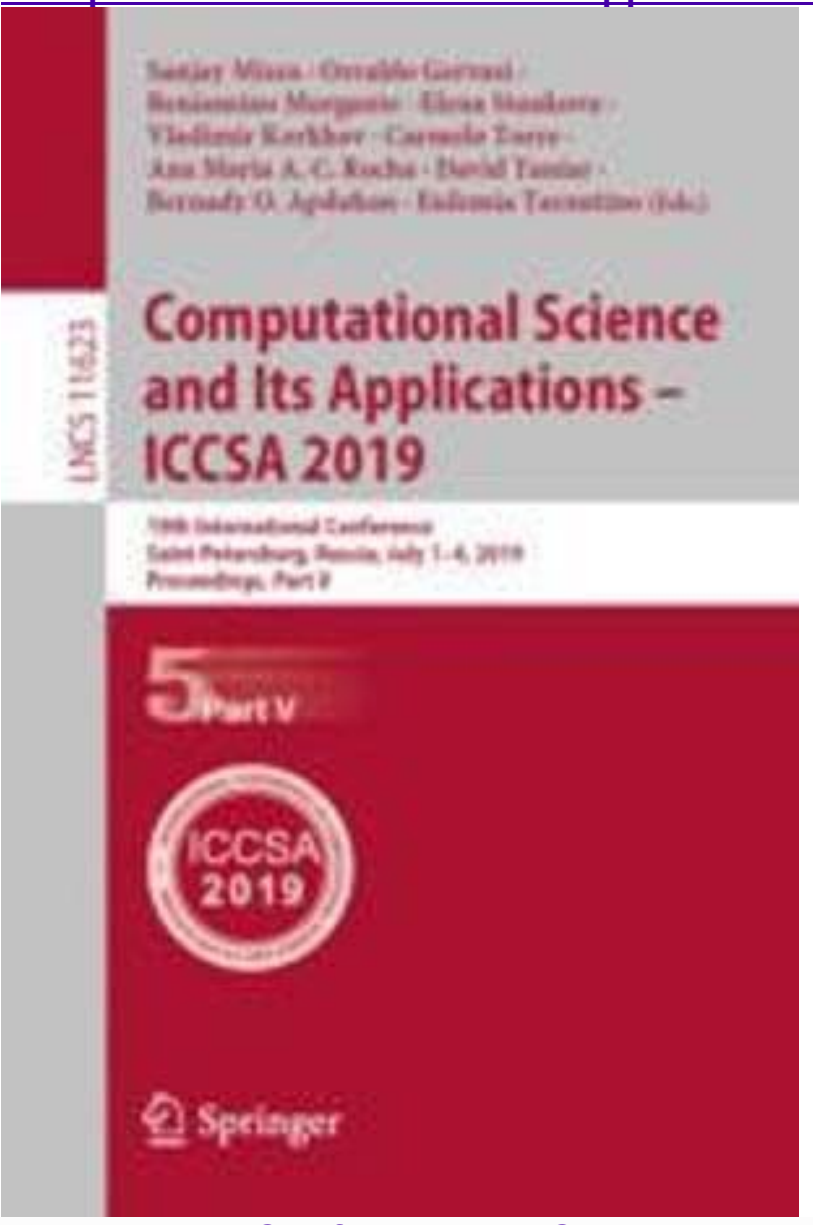

International Conference on Computational Science and Its Applications

ICCSA 2019: Computational Science and Its Applications - ICCSA 2019 pp 372382| $\underline{\text { Cite as }}$

\title{
Improving Employability Skills Through a Web-Based Work Integrated Learning Database for Construction Students
}

- Authors

- Authors and affiliations

- Adedeji Afolabi

- Ibukun Afolabi

- Emmanuel Eshofonie

- Faith Akinbo 
Conference paper

First Online: 29 June 2019

\section{- 521Downloads}

Part of the Lecture Notes in Computer Science book series (LNCS, volume 11623)

\section{Abstract}

Employability and Unemployment continues to be dire issues that Nigerian youth are faced with daily in a saturated employment market. Whereas, the use of workintegrated learning can help bridge the gap by increasing employability skills among students. The study examined the benefits of having a work-integrated learning (WIL) program for students in the construction field. Therefore, the study developed a framework for improving employability skills through a web-based work integrated learning database for construction students. Using a system block diagram, use case diagram and activity diagram, the study illustrated the functional requirement needed for the development of the WIL platform. The WIL platform is a web-based system pooling submission of available WIL positions from employers in construction businesses and former WIL students in order for prospective WIL students to access possible openings where they can learn in a workplace environment. The methodology of this research includes using the combination of HTML, CSS and the C-Sharp programming language for the interface design and server side scripting while MySQL was the database platform used for storing and retrieving the data used for the application. In conclusion, the study designed a WIL platform for construction students. The use of the WIL platform is intended to encourage employability of construction students by ensuring that they are adequately engaged in a work place training.

\section{Keywords}

Construction students Employability Work-integrated learning

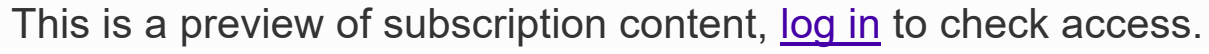

\section{Notes}

\section{Acknowledgement}

The authors appreciate the kind efforts of Covenant University through its Centre for Research, Innovation and Discovery in paying for the article processing charge of this article.

\section{References}

1. 1. 
National Bureau of Statistics, NBS: Labour Force Statistics Vol. 1: Unemployment and Underemployment Report (Q1- Q3 2017), FOS, Nigeria (2017)Google Scholar

2. 2 .

Jackson, D.: The contribution of work-integrated learning to undergraduate employability skills outcomes. Asia-Pacific J . Coop. Educ. 14(2), 99- 115 (2013)Google $\underline{\text { Scholar }}$

3. 3

Paadi, K.: Perceptions on employability skills necessary to enhance human resource management graduates prospects of securing a relevant place in the labour market. Eur. Sci. J. Spec. Ed. 10, 129- 143 (2014)Google Scholar

4. 4.

Martin, A., Rees, M.: Work Integrated Learning: More than Enhancing Employability and Graduate Attributes. "The Most Beneficial and Rewarding Part of My University Experience”, pp. 1- 70. Ako Aotearoa, Wellington (2018)Google Scholar

5. 5 .

Afolabi, A.O., Ojelabi, R.A., Bukola, A., Akinola, A., Afolabi, A.: Statistical exploration of dataset examining key indicators influencing housing and urban infrastructure investments in megacities. Data Brief 18, 1725- 1733 (2018)CrossRefGoogle Scholar

6. 6 .

Afolabi, A., Ojelabi, R., Tunji-Olayeni, P.F., Omuh, I., Afolabi, A.: Quantitative analysis of socio-economic drivers of housing and urban development projects in megacities. Int. J . Civil Eng. Technol. 9(6), 1096- 1106 (2018) Google Scholar

7. 7.

Afolabi, A.O., Oyeyipo, O.: The perception of future decision-makers on the building profession. Malays. Constr. Res. J . 21(1), 55- 73 (2017) Google Scholar

8. 8.

Patrick, C-J ., Peach, D., Pocknee, C., Webb, F., Fletcher, M., Pretto, G.: The WIL [work integrated learning] report: a national scoping study. Australian Learning and Teaching Council (ALTC) Final report. Queensland University of Technology, Brisbane (2008). www.altc.edu.au, www.acen.edu.au

9. 9.

Martin, A., Hughes, H.: How to make the most of work-integrated learning. Massey University, Palmerston North (2009) Google Scholar 
10.10.

Al-Shehri, W.: Work integrated learning (WIL) in virtual reality (VR). Department of Computing, Macquarie University

(2012). https:// arxiv.org/ftp/arxiv/ papers/ 1211/ 1211.2412.pdf

Campbell, M., Zegwaard, K.E.: Ethical considerations and values development in workintegrated learning programs. In: Conference Proceedings, New Zealand Association for Cooperative Education, Napier (2011) Google Scholar

McLennan, B., Keating, S.: Work-integrated learning (WIL) in Australian universities: the challenges of mainstreaming WIL. In: ALTC NAGCAS National Symposium, Melbourne (2008) Google Scholar

Masum, R., Lodhi, M.S.: impact of work-integrated learning on masters of business administration students: employers' perspective, pp. 1-20 (2015). https:// www.researchgate.net/publication/320010936 IMPACT OF WORKINTEGRATED LEARNING ON MASTERS OF BUSINESS_ADMINISTRATION S TUDENTS EMPLOYERS' PERSPECTIVE

Rambe, P.: Using work integrated learning programmes as a strategy to broaden academic and workplace competencies. SA J. Hum. Resour. Manag. 16, 1- 19 (2018)Google Scholar

15.15.

Ferns, S., Russell, L., Kay, J., Smith, J .: Responding to industry needs for proactive engagement in work integrated learning (WIL): partnerships for the future, pp. 88- 95 (2016). https:// eprints.qut.edu.au/ 105593/2/105593\%28paper\%29.pdf

16. 16.

Bandaranaike, S., Willison, J .: Building capacity for work-readiness: Bridging the cognitive and affective domains. Asia-Pacific J . Coop. Educ. 16(3), 223- 233 (2015)Google Scholar

Bates, M.: Preparing Professionals for Autonomy: Workplace-Based Courses in Professional Education. VDM Verlag Dr Muller, Saarbrucken (2008)Google Scholar 
18. 18.

Afolabi, A., Ojelabi, R., Amusan, L., Adefarati, F.: Development of a web-based building profession career panel as a guidance information system for secondary school students. In: International Conference on Computing Networking and Informatics (ICCNI), IEEE, Lagos, Nigeria, pp. 1- 10 (2017) Google Scholar

19.19.

Afolabi, A.O., Ojelabi, R.A., Oyeyipo, O., Tunji-Olayeni, P.F., Omuh, I.O.: Integrating Software development courses in the construction curriculum. Turk. Online J. Educ. Technol. Spec. Issue, 215- 225 (2017) Google Scholar

\section{Copyright information}

(C) Springer Nature Switzerland AG 2019

\section{About this paper}

CrossMark

\section{Cite this paper as:}

Afolabi A., Afolabi I., Eshofonie E., Akinbo F. (2019) Improving Employability

Skills Through a Web-Based Work Integrated Learning Database for

Construction Students. In: Misra S. et al. (eds) Computational Science and Its

Applications - ICCSA 2019. ICCSA 2019. Lecture Notes in Computer

Science, vol 11623. Springer, Cham

- First Online29 June 2019

- DOlhttps://doi.org/10.1007/978-3-030-24308-1_31

- Publisher NameSpringer, Cham

- Print ISBN978-3-030-24307-4

- Online ISBN978-3-030-24308-1

- eBook Packages $\underline{\text { Computer Science }}$

\section{Buy eBook}

EUR 82.38

Buy paper (PDF)

EUR 24.95

- Contact us

Springer Nature

(C) 2019 Springer Nature Switzerland AG. Part of Springer Nature. 
Not logged in Not affiliated 165.73.223.242 